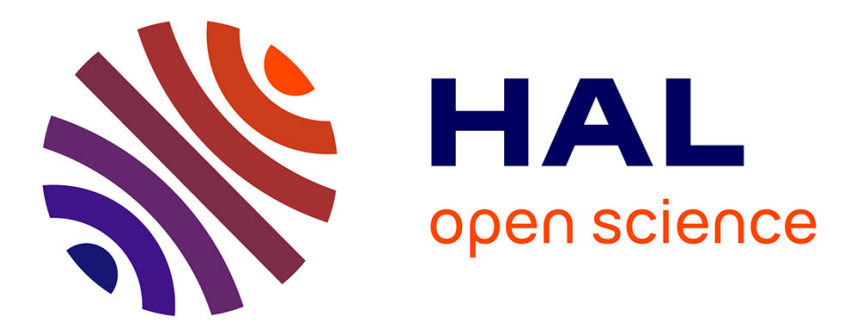

\title{
Effect of Load Cycling on the Performance of Fuel Cell Stacks
}

Elodie Pahon, Samir Jemei, Nadia Yousfi Steiner, Daniel Hissel

\section{To cite this version:}

Elodie Pahon, Samir Jemei, Nadia Yousfi Steiner, Daniel Hissel. Effect of Load Cycling on the Performance of Fuel Cell Stacks. Vehicle Power and Propulsion Conference, Oct 2019, Hanoi, Vietnam. hal-02991594

\section{HAL Id: hal-02991594 https://hal.science/hal-02991594}

Submitted on 6 Nov 2020

HAL is a multi-disciplinary open access archive for the deposit and dissemination of scientific research documents, whether they are published or not. The documents may come from teaching and research institutions in France or abroad, or from public or private research centers.
L'archive ouverte pluridisciplinaire HAL, est destinée au dépôt et à la diffusion de documents scientifiques de niveau recherche, publiés ou non, émanant des établissements d'enseignement et de recherche français ou étrangers, des laboratoires publics ou privés. 


\section{Effect of load cycling on the performance of fuel cell stacks}

\author{
Elodie Pahon \\ FEMTO-ST, CNRS, Univ. \\ Bourgogne Franche-Comte \\ FCLAB, CNRS, Univ. Bourgogne \\ Franche-Comte \\ Rue Thierry Mieg, F-90010 \\ Belfort Cedex, France \\ elodie.pahon@femto-st.fr
}

\author{
Samir Jemei \\ FEMTO-ST, CNRS, Univ. \\ Bourgogne Franche-Comte \\ FCLAB, CNRS, Univ. Bourgogne \\ Franche-Comte \\ Rue Thierry Mieg, F-90010 \\ Belfort Cedex, France \\ samir.jemei@ubfc.fr
}

\author{
Nadia Yousfi Steiner \\ FEMTO-ST, CNRS, Univ. \\ Bourgogne Franche-Comte \\ FCLAB, CNRS, Univ. Bourgogne \\ Franche-Comte \\ Rue Thierry Mieg, F-90010 \\ Belfort Cedex, France \\ nadia.steiner@univ-fcomte.fr
}

\author{
Daniel Hissel \\ FEMTO-ST, CNRS, Univ. \\ Bourgogne Franche-Comte \\ FCLAB, CNRS, Univ. Bourgogne \\ Franche-Comte \\ Rue Thierry Mieg, F-90010 \\ Belfort Cedex, France \\ daniel.hissel@ubfc.fr
}

\begin{abstract}
The durability and the reliability of fuel cells are key points to continue to promote hydrogen energy as an efficient solution to face the global warming and the dependency to fossil fuels. Some long duration tests are needed to evaluate the performance losses of the fuel cell. This paper deals with the study of a proton exchange membrane fuel cell degradation due to different load cycling profiles. Based on a reference cycle, two other profiles are designed, by increasing the frequency and the magnitude of the load cycling. The impact of these two stressor factors, on short fuel cell stacks, is given as results.
\end{abstract}

Keywords-Load cycling, proton exchange membrane fuel cell, durability test, degradation analysis.

\section{INTRODUCTION}

The durability of fuel cell systems needs to be increased. For transport applications, the Department of Energy (DOE) gave the objectives for 2025 and identified a durability target of 8000 hours (for fuel cell cars) with less than $10 \%$ loss of performance in order to meet commercial requirement [1]. To find solutions for the durability of fuel cells, there are two main ways: $\boldsymbol{i}$ ) study new innovative materials to improve the lifetime of fuel cell systems by considering the catalyst structure [2], the catalyst support [3], hydrophobic doping for catalyst layers [4] and/or ii) develop additional approaches as diagnostics, prognostics and fault tolerant control dedicated to the fuel cell system [5-9].

The ageing of a fuel cell can be due to several kinds of degradation, which lead to a fuel cell voltage decrease, $i$ ) natural ageing that is irreversible because of material loss along time (such as loss of catalyst support), ii) undesired shut-off and iii) degradation due to transients (load cycling). Breaz et al. [10] present a short review of the aging mechanisms modeling for a proton exchange membrane (PEM) fuel cell in automotive applications. In transportation applications, the operating conditions change frequently and the lifetime is reduced. Thus, durability tests have to be done to compare the performance of fuel cell stack and determine what are the stressor parameters during a load cycle. Petrone et al. [11] suggest an accelerated stress test based on the load profile in order to improve the proton exchange membrane fuel cell (PEMFC) lifetime. The amplitude and the frequency of the cycle are especially investigated.

In this paper, three durability tests are performed on shortstacks in order to observe the degradation during load cycles and

\footnotetext{
Identify applicable funding agency here. If none, delete this text box.
}

determine which stress parameter prevails between magnitude of the current step (especially positive current steps) and the frequency of the cycle (total number of cycle repetitions and total number of positive current steps).

This paper is organized as follows, in section II, the test plans are presented with stack specifications, test profiles and characterization protocols. Section III presents the experimental results and the degradation rates according to each test profile. Section IV presents a conclusion of this work.

\section{TEST Plans}

In order to study the impact of two parameters on the fuel cell degradation, three experimental tests are performed. The main goal is to observe how the frequency of a cycle and the magnitude of the current step affect the fuel cell stack.

\section{A. Fuel cell specifications}

In the framework of the European project SAPPHIRE, all stacks tested were manufactured at the Centre for Solar Energy and Hydrogen Research (ZSW) to ensure the same stack design (gas flow field, gas flow direction, etc.) for all laboratories. Anode and cathode gas were fed in counter-flow with the cooling flow in co-flow direction to cathode gas. Table 1 presents stack specifications.

TABLE I. SHORT-STACK SPECIFICATIONS

\begin{tabular}{|l|c|}
\hline \multicolumn{1}{|c|}{ Parameters } & Values [unit] \\
\hline Active area & $100 \mathrm{~cm}^{2}$ \\
\hline Cell number & 5 \\
\hline Inlet pressure anode/cathode & $200 / 150 \mathrm{mbarg}$ \\
\hline Inlet temperature & $60{ }^{\circ} \mathrm{C}$ \\
\hline Inlet relative humidity & $100 \%$ \\
\hline Stoichiometry anode/cathode & $\begin{array}{r}1.3 / 2 @ 0.35 \mathrm{~A} / \mathrm{cm}^{2} \\
1.5 / 3 @ 0.15 \mathrm{~A} / \mathrm{cm}^{2} \\
1.4 / 2.5 @ 0.25 \mathrm{~A} / \mathrm{cm}^{2}\end{array}$ \\
\hline
\end{tabular}

\section{B. Profile designs}

In this study, the performance losses of three long duration tests are investigated. The profile 1 is the reference signal with low dynamics. The profile 2 is a more dynamic one; the frequency of the cycle is increased. The profile 3 is similar to 
the profile 2 but the magnitude is doubled. The profile 2 allows investigating the impact of the frequency on the fuel cell degradation whereas the profile 3 allows studying the degradation due to the magnitude of the positive current step. Figure 1 presents the three different test profiles.

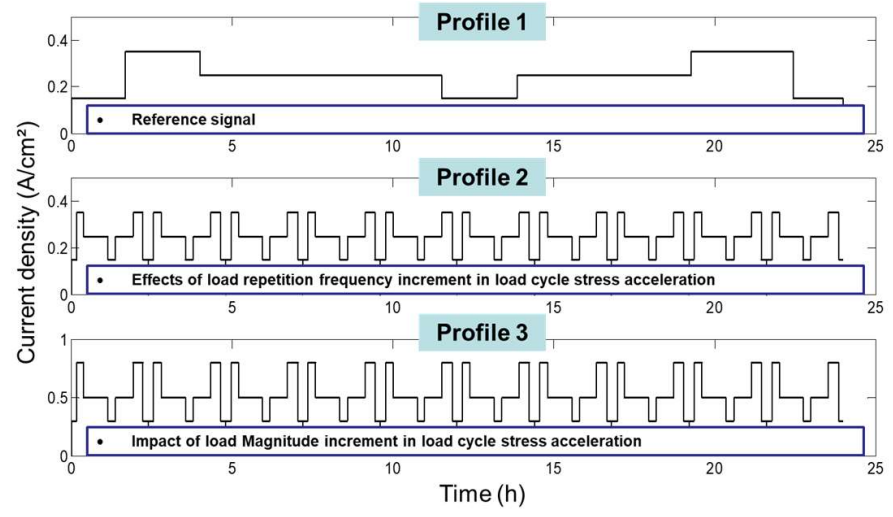

Fig. 1. Long-duration tests investigated in the study

\section{Characterization protocol}

Two different analysis techniques for in-situ analysis (electrochemical impedance spectroscopy and polarization curves) are selected as main tools to be performed during stack tests. The characterization protocol is composed of (in order of realization):

1. A polarization curve

2. The electrochemical impedance spectra (EIS) at the lowest current density: $0.15 \mathrm{~A} / \mathrm{cm}^{2}$ (profiles $1 \& 2$ ) or 0.30 $\mathrm{A} / \mathrm{cm}^{2}$ (profile 3 )

3. The EIS at the middle current density: $0.25 \mathrm{~A} / \mathrm{cm}^{2}$ (profiles $1 \& 2$ ) or $0.50 \mathrm{~A} / \mathrm{cm}^{2}$ (profile 3)

4. The EIS at $0.35 \mathrm{~A} / \mathrm{cm}^{2}$ (profiles $1 \& 2$ ) or $0.70 \mathrm{~A} / \mathrm{cm}^{2}$ (profile 3)

The frequency range considered for the EIS is comprised between $5 \mathrm{kHz}$ and $100 \mathrm{mHz}$. For the polarization curve, the time step is 15 minutes using a stability criterion of $\pm 5 \mathrm{mV}$ for the last 5 minutes based on the average cell voltage. At low current densities, under a minimum gas flow corresponding to $20 \%$ of the nominal value $\left(0.66 \mathrm{~A} / \mathrm{cm}^{2}\right)$, the hold time is reduced to 1 minute to avoid stack damage by dry out and/or degradation. For the same purpose, OCV hold time should be reduced to 5 seconds. Subsequently, the current density is stepwise increased to the maximum to determine the ascending polarization curve measured with increasing electrical power output.

\section{RESULTS}

\section{A. Profile 1}

Figure 2 shows the duration profile over the total amount of 2155 operating hours excluding fuel cell conditioning. Once a week electrochemical characterization was performed (polarization curve \& electrochemical impedance spectroscopy). Due to the regular current cycling the stack voltage is decreasing. Cells numbering and the relative position of the gas inputs and outputs are schematized in table 2. In addition, the degradation rate of each cell is specified. The degradation rate is calculated in two different ways:

i) The single cell voltage levels at a current density of a $0.25 \mathrm{~A} / \mathrm{cm}^{2}$ during duration profile are considered. The reference time represents the cycling duration of 1537 hours at $65^{\circ} \mathrm{C}$.

ii) The decrease of voltages at a current density of 0.22 $\mathrm{A} / \mathrm{cm}^{2}$ is calculated over the total experiment time at $65^{\circ} \mathrm{C}$. The characterization time is included into the second type of averaging.

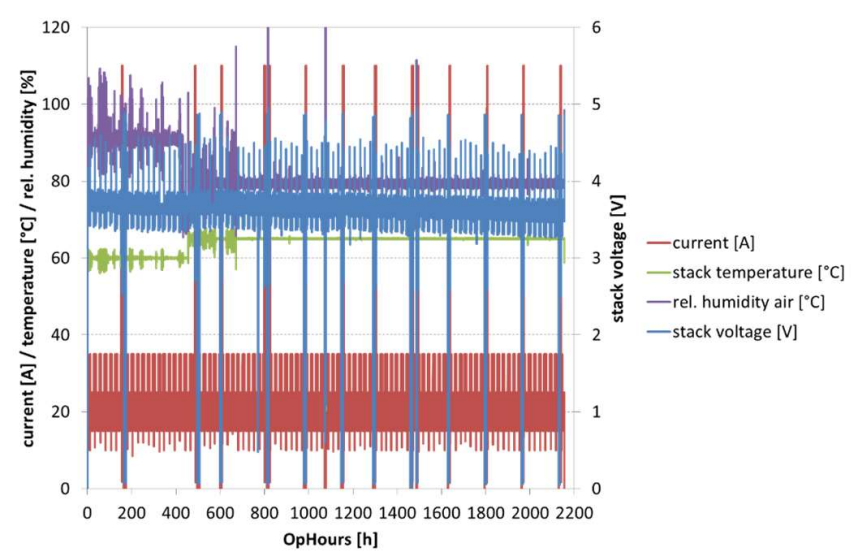

Fig. 2. Duration profile with 1 cycle per day $\left(456 \mathrm{~h}\right.$ at $60^{\circ} \mathrm{C}, 1699 \mathrm{~h}$ at $\left.65^{\circ} \mathrm{C}\right)$

The average degradation rate of cells is $14.3 / 14.9 \mu \mathrm{V} / \mathrm{h}$ calculated during duration profile / polarization curve. The cell voltage 2 is decreasing more slowly than other, unlike the cell 5, which is decreasing faster, but still within the same order of magnitude. The voltage decays calculated using duration profile and polarization curve data are almost the same, as both operating conditions are comparable and overall non-degrading.

TABLE II. CELLS NUMBERING AND DEGRADATION RATES CALCULATED DURING DURATION PROFILE AND POLARIZATION CURVE FOR PROFILE 1

\begin{tabular}{|c|c|c|}
\hline $\begin{array}{c}\text { Cathode (gas and } \\
\text { coolant inlets and } \\
\text { outlets) }\end{array}$ & $\begin{array}{l}\text { Degradation at } 0.25 \\
\text { A/cm at } 65^{\circ} \mathrm{C} \text { cell } \\
\text { temperature with } \\
\text { reference to time of } \\
\text { duration profile }\end{array}$ & $\begin{array}{c}\text { Degradation at } 0.22 \\
\text { A/cm }{ }^{2} \text { at } 65^{\circ} \mathrm{C} \text { cell } \\
\text { temperature during } \\
\text { polarization curve } \\
\text { with reference to } \\
\text { total time }\end{array}$ \\
\hline Cell 5 & $-17.1 \mu \mathrm{V} / \mathrm{h}$ & $-18.1 \mu \mathrm{V} / \mathrm{h}$ \\
\hline Cell 4 & $-12.1 \mu \mathrm{V} / \mathrm{h}$ & $-13.5 \mu \mathrm{V} / \mathrm{h}$ \\
\hline Cell 3 & $-13.3 \mu \mathrm{V} / \mathrm{h}$ & $-13.7 \mu \mathrm{V} / \mathrm{h}$ \\
\hline Cell 2 & $-13.1 \mu \mathrm{V} / \mathrm{h}$ & $-14.9 \mu \mathrm{V} / \mathrm{h}$ \\
\hline Cell 1 & $-16.6 \mu \mathrm{V} / \mathrm{h}$ & $-16.1 \mu \mathrm{V} / \mathrm{h}$ \\
\hline Anode & & \\
\hline
\end{tabular}

Figure 3 presents the change in impedance spectra during the duration profile. The high frequency resistance (HFR) changes insignificantly to higher or lower values over the total experiment time. The low frequency resistance (LFR) shifts steadily to higher values. The LFR increases from $803 \mathrm{~h}$ to $1795 \mathrm{~h}$ by $2.7-6 \%$. 


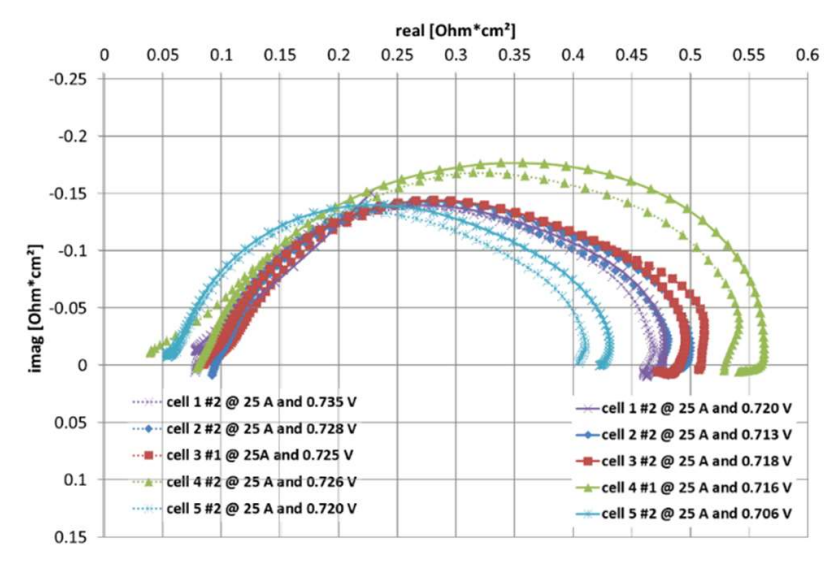

Fig. 3. Impedance spectra at $0.25 \mathrm{~A} / \mathrm{cm}^{2}$ of 5 -cell stack after $803 \mathrm{~h}$ (dashed) and $1795 \mathrm{~h}$ (solid)

\section{B. Profile 2}

Figure 4 shows the total duration profile of 1781 operating hours excluding conditioning time. For the first 151 operating hours, the stack was cycled with one cycle per day as described. For the following 1630 hours, the 5-cell stack was cycled with a higher current frequency (10 times more intensive). The performance of cell 5 decreased significantly with the first 650 operation hours. Cell 4 revealed the same performance loss within the first 1000 operating hours. The degradation of cells 1 to 3 was less significant.

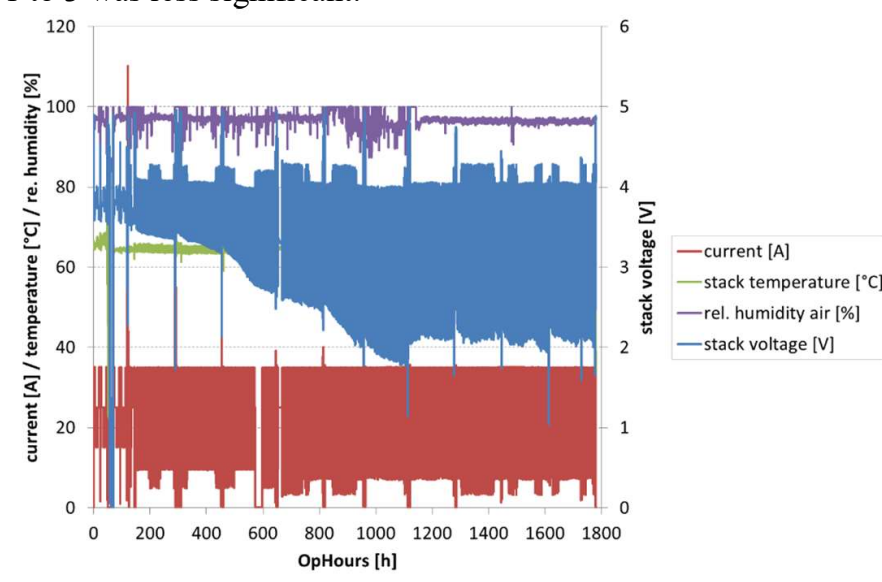

Fig. 4. 5-cell PEMFC stack tested with 1 cycle per day for $151 \mathrm{~h}, 10$ cycles per day for $1630 \mathrm{~h}$

Two cells within the 5-cell stack showed a severe degradation leading to single cell voltage levels below normal operating performance. The voltage drops of cells 4 and 5 led to an unsteady operation with overall stable single cell voltage level. The cells numbering and the relative position of the gas input and output are schematized in table 3 . The degradation rates are calculated to be twice as large as described in the previous section. The degradation rates are calculated with reference to time of duration profile / polarization curve.

The other cells 1 to 3 reveal a degradation rate to round 28.8/ $29.6 \mu \mathrm{V} / \mathrm{h}$. Correlating the degradation effect to the current cycling frequency, the degradation is enhanced by a factor 2 by decoupling of load changes (if considering only the three first cells).

TABLE III. CELLS NUMBERING AND DEGRADATION RATES CALCULATED DURING DURATION PROFILE AND POLARIZATION CURVE FOR PROFILE 2

\begin{tabular}{|c|c|c|}
\hline $\begin{array}{c}\text { Cathode (gas and } \\
\text { coolant inlets and } \\
\text { outlets) }\end{array}$ & $\begin{array}{c}\text { Degradation at 0.25 } \\
\text { A/cm } \text { cmith reference to }_{\text {time of duration profile }}\end{array}$ & $\begin{array}{c}\text { Degradation at 0.22 } \\
\text { A/cm } \text { during }^{2} \\
\text { polarization curve } \\
\text { with reference to } \\
\text { total time }\end{array}$ \\
\hline Cell 5 & $-132 \mu \mathrm{V} / \mathrm{h}$ & $-90 \mu \mathrm{V} / \mathrm{h}$ \\
\hline Cell 4 & $-109 \mu \mathrm{V} / \mathrm{h}$ & $-78 \mu \mathrm{V} / \mathrm{h}$ \\
\hline Cell 3 & $-30.5 \mu \mathrm{V} / \mathrm{h}$ & $-34 \mu \mathrm{V} / \mathrm{h}$ \\
\hline Cell 2 & $-30 \mu \mathrm{V} / \mathrm{h}$ & $-28 \mu \mathrm{V} / \mathrm{h}$ \\
\hline Cell 1 & $-26 \mu \mathrm{V} / \mathrm{h}$ & $-27 \mu \mathrm{V} / \mathrm{h}$ \\
\hline Anode & & \\
\hline
\end{tabular}

\section{Profile 3}

For the last test, what is interesting to observe is the possible impact (or not) of the amplitude of the current on the degradation of the fuel cell (and therefore if it is a parameter susceptible to accelerate the ageing). For this, all amplitudes are doubled. Therefore, the 4 considered current densities levels are: $\mathrm{OCV}, 0.3,0.5$ and $0.7 \mathrm{~A} / \mathrm{cm}^{2}$. The operating conditions are maintained similar to the previous ones. The only change concerns stoichiometries. They are kept constant instead of varying with the current density. The anode stoichiometry is fixed to 2.5 and the cathode stoichiometry is 3 . Figure 5 presents the evolution of the stack voltage, the current and the temperature.

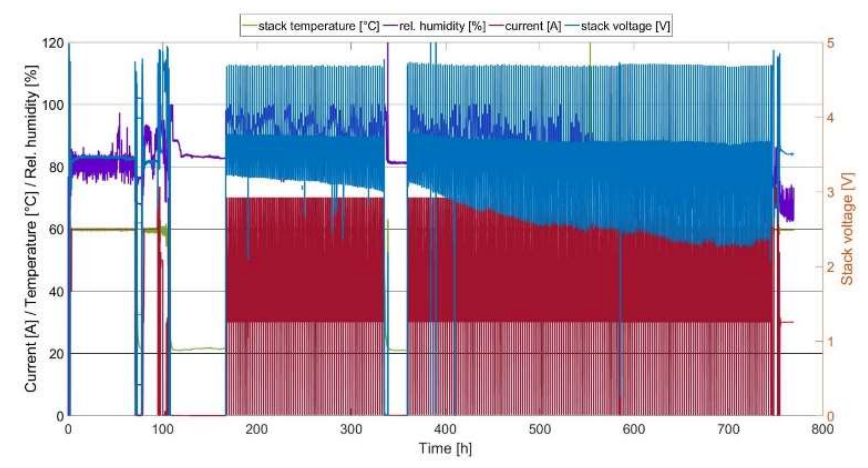

Fig. 5. 5-cell PEMFC stack tested with conditioning phase ( $\mathrm{t}=0$ until $\mathrm{t}=180 \mathrm{~h})$ and 10 cycles per day with the amplitude doubled for $570 \mathrm{~h}$

It can be noticed that the degradation is much higher for the two last cells (cells $4 \& 5$ ). Tables 4 and 5 confirm this trend by proposing the degradation rates cell per cell and for each current densities, during polarization curve with reference to total time and with reference to time of duration profile. The high degradation of these two cells could be due to their position in the stack. They are located near to the gas and coolant inlets and the anode and cathode gas were fed in counter-flow with the cooling flow in co-flow direction to cathode gas. Moreover, the load profile is twice bigger than the profile 2 , and the potential 
ranges are different. Thus, additional degradation occurred as the potential cycling is higher. When considering the current density of $0.3 \mathrm{~A} / \mathrm{cm}^{2}$, the degradation is quite similar to the previous performance losses, on profile 2 , at $0.25 \mathrm{~A} / \mathrm{cm}^{2}$.

TABLE IV. CELLS NUMBERING AND DEGRADATION RATES CALCULATED DURING POLARIZATION CURVE FOR PROFILE 3

\begin{tabular}{|c|c|c|c|}
\hline $\begin{array}{l}\text { Cathode (gas } \\
\text { and coolant } \\
\text { inlets and } \\
\text { outlets) }\end{array}$ & $\begin{array}{c}\text { Degradation at } \\
0.7 \mathrm{~A} / \mathrm{cm}^{2} \\
\text { during } \\
\text { polarization } \\
\text { curve with } \\
\text { reference to } \\
\text { total time }\end{array}$ & $\begin{array}{c}\text { Degradation at } 0.5 \\
\text { A/cm }{ }^{2} \text { during } \\
\text { polarization curve } \\
\text { with reference to } \\
\text { total time }\end{array}$ & $\begin{array}{c}\text { Degradation at } \\
0.3 \mathrm{~A} / \mathrm{cm}^{2} \text { during } \\
\text { polarization curve } \\
\text { with reference to } \\
\text { total time }\end{array}$ \\
\hline Cell 5 & $-459 \mu \mathrm{V} / \mathrm{h}$ & $-211 \mu \mathrm{V} / \mathrm{h}$ & $-103 \mu \mathrm{V} / \mathrm{h}$ \\
\hline Cell 4 & $-374 \mu \mathrm{V} / \mathrm{h}$ & $-207 \mu \mathrm{V} / \mathrm{h}$ & $-116 \mu \mathrm{V} / \mathrm{h}$ \\
\hline Cell 3 & $-66 \mu \mathrm{V} / \mathrm{h}$ & $-27 \mu \mathrm{V} / \mathrm{h}$ & $-21 \mu \mathrm{V} / \mathrm{h}$ \\
\hline Cell 2 & $-11 \mu \mathrm{V} / \mathrm{h}$ & $-9 \mu \mathrm{V} / \mathrm{h}$ & $-6 \mu \mathrm{V} / \mathrm{h}$ \\
\hline Cell 1 & $-6 \mu \mathrm{V} / \mathrm{h}$ & $-5 \mu \mathrm{V} / \mathrm{h}$ & $-2 \mu \mathrm{V} / \mathrm{h}$ \\
\hline Anode & & & \\
\hline
\end{tabular}

TABLE V. CELLS NUMBERING AND DEGRADATION RATES CALCULATED DURING DURATION PROFILE FOR PROFILE 3

\begin{tabular}{|c|c|c|c|}
\hline $\begin{array}{c}\text { Cathode (gas } \\
\text { and coolant } \\
\text { inlets and } \\
\text { outlets) }\end{array}$ & $\begin{array}{c}\text { Degradation at } \\
0.7 \mathrm{~A} / \mathrm{cm}^{2} \\
\text { during } \\
\text { polarization } \\
\text { curve with } \\
\text { reference to } \\
\text { total time }\end{array}$ & $\begin{array}{c}\text { Degradation at } 0.5 \\
A / \text { cm }^{2} \text { during } \\
\text { polarization curve } \\
\text { with reference to } \\
\text { total time }\end{array}$ & $\begin{array}{c}\text { Degradation at } \\
0.3 \mathrm{~A} / \mathrm{cm}^{2} \text { during } \\
\text { polarization curve } \\
\text { with reference to } \\
\text { total time }\end{array}$ \\
\hline Cell 5 & $-418 \mu \mathrm{V} / \mathrm{h}$ & $-162 \mu \mathrm{V} / \mathrm{h}$ & $-75 \mu \mathrm{V} / \mathrm{h}$ \\
\hline Cell 4 & $-363 \mu \mathrm{V} / \mathrm{h}$ & $-176 \mu \mathrm{V} / \mathrm{h}$ & $-91.25 \mu \mathrm{V} / \mathrm{h}$ \\
\hline Cell 3 & $-70 \mu \mathrm{V} / \mathrm{h}$ & $-40 \mu \mathrm{V} / \mathrm{h}$ & $-14 \mu \mathrm{V} / \mathrm{h}$ \\
\hline Cell 2 & $-19 \mu \mathrm{V} / \mathrm{h}$ & $-10 \mu \mathrm{V} / \mathrm{h}$ & $-9 \mu \mathrm{V} / \mathrm{h}$ \\
\hline Cell 1 & $-7.5 \mu \mathrm{V} / \mathrm{h}$ & $-4 \mu \mathrm{V} / \mathrm{h}$ & $0 \mu \mathrm{V} / \mathrm{h}$ \\
\hline Anode & & & \\
\hline
\end{tabular}

\section{CONCLUSION}

The load cycling impact on a PEMFC performance is investigated in this study. Three long duration tests have been performed in order to observe the degradation due to two stress factors: the frequency of the load cycling and the magnitude of the load step. According to table 3, it can be noticed that the frequency increases the fuel cell performance losses. The average degradation on the stack has been doubled between the profile 1 ( 1 cycle per day) and the profile 2 with higher dynamic ( 10 cycles per day). The magnitude of the current step is studied with the profile 3 . According to tables $3 \& 4$, the degradation is quite similar.
Thus, it can be concluded that the increasing of the magnitude did not affect the fuel cell degradation. These conclusions should help to understand the fuel cell behavior according to a load profile in order to increase its durability and going further with accelerated stress tests, especially important when considering automotive applications of fuel cells.

\section{ACKNOWLEDGMENT}

The research leading to these results has received funding from the European Union's Seventh Framework Program (FP7/2007-2013) for the Fuel Cells and Hydrogen Joint Technology Initiative under grant agreement $\mathrm{N}^{\circ} 325275$. The authors also acknowledge EIPHI Graduate School (contract "ANR-17-EURE-0002"), for financially supporting this work.

\section{REFERENCES}

[1] DOE Hydrogen 2017, "Fuel cell Technical Team Roadmap", 2017, pp. 1-302.

[2] E. Carcadea, M. Varlam, A. Marinoiu, M. Raceanu, M.S. Isamil, D.B. Ingham, "Influence of catalyst structure of PEM fuel cell performance A numerical investigation", Int. J. Hydrogen Energy, In Press, Corrected Proof, 2019, pp. 1-13.

[3] L. Du, Y. Shao, J. Sun, G. Yin, J. Liu, Y. Wang, "Advanced catalyst supports for PEM fuel cell cathodes", Nano Energy, vol. 29, 2016, pp. 314-322.

[4] G.S. Avcioglu, B. Ficicilar, I. Eroglu, "Improved PEM fuel cell performance with hydrophobic catalyst layers", Int. J. Hydrogen Energy, vol. 43, no 40, 2018, pp. 18632-18641.

[5] S. Morando, M.C. Péra, N. Yousfi-Steiner, S. Jemei, D. Hissel and L. Larger, "Fuel Cells Fault Diagnosis under Dynamic Load Profile Using Reservoir Computing," 2016 IEEE Vehicle Power and Propulsion Conference (VPPC), Hangzhou, 2016, pp. 1-6.

[6] G. Dotelli, R. Ferrero, P. G. Stampino, S. Latorrata and S. Toscani, "Diagnosis of PEM Fuel Cell Drying and Flooding Based on Power Converter Ripple," in IEEE Transactions on Instrumentation and Measurement, vol. 63, no. 10, pp. 2341-2348, Oct. 2014.

[7] A. H. Detti, S. Jemei and N. Yousfi-Steiner, "Proton Exchange Membrane Fuel Cell Model for Prognosis," 2018 IEEE Vehicle Power and Propulsion Conference (VPPC), Chicago, IL, 2018, pp. 1-6.

[8] D. Zhou, Y. Wu, F. Gao, E. Breaz, A. Ravey and A. Miraoui, "Degradation Prediction of PEM Fuel Cell Stack Based on Multiphysical Aging Model With Particle Filter Approach," in IEEE Transactions on Industry Applications, vol. 53, no. 4, pp. 4041-4052, July-Aug. 2017.

[9] E. Dijoux, M. Benne, N. Yousfi Steiner, B. Grondin Perez and M. Pera, "Active Fault Tolerant Control Strategy Applied to PEMFC Systems," 2017 IEEE Vehicle Power and Propulsion Conference (VPPC), Belfort, 2017, pp. 1-5.

[10] E. Breaz, F. Gao, A. Miraoui and R. Tirnovan, "A short review of aging mechanism modeling of proton exchange membrane fuel cell in transportation applications," IECON 2014 - 40th Annual Conference of the IEEE Industrial Electronics Society, Dallas, TX, 2014, pp. 3941-3947.

[11] R. Petrone, R. Yeetsorn, F. Harel, D. Hissel, M.C. Péra, E. Breaz and S. Giurgea, "Accelerated Stress Tests Oriented Load Profile for PEM Fue Cells Durability in Automotive Applications," 2017 IEEE Vehicle Power and Propulsion Conference (VPPC), Belfort, 2017, pp. 1-5. 